\title{
Impact of ivermectin-resistant gastrointestinal nematodes in feedlot cattle in Argentina ${ }^{1}$
}

\author{
Luis E. Fazzio ${ }^{2 *}$, Nicolas Yacachury², Walter R. Galvan², Elias Peruzzo², Ricardo O. \\ Sánchez ${ }^{3}$ and Eduardo J. Gimeno ${ }^{2}$
}

\begin{abstract}
Fazzio L.E, Yacachury N., Galvan W.R., Peruzzo E., Sanchez R.O. \& Gimeno E.J. 2012. Impact of ivermectin-resistant gastrointestinal nematodes in feedlot cattle in Argentina. Pesquisa Veterinária Brasileira 32(5):419-423. Facultad de Ciencias Veterinarias, Universidad Nacional de La Plata, calle 60 y 118, CC 296, B1900AVW, La Plata, Argentina. E-mail: fazzio@fcv.unlp.edu.ar

The aim was to evaluate for 75 days the impact on production of the remaining burden of ivermectin (IVM)-resistant parasites in naturally infected feedlot calves. The herds came from tick-infested areas of cattle breeding where the systematic use of IVM to control tick increases the gastrointestinal parasites resistant to this drug. This investigation was carried out in two commercial feedlots in Buenos Aires province. In feedlot A, two groups of 35 animal each received IVM $1 \%$ and the other received ricobendazole (RBZ) $10 \%$ respectively. The same was done in feedlot B. On day 0 , two groups of 35 animals were made in feedlots A and B. Fecal samples were taken on days $0,22,54$ and 75 pos-treatment (PT), and body weight was registered, from each animal. Fecal samples were processed for individual count of eggs per gram (EPG) and pooled fecal culture was carried out for identification of the parasite genus in each sampling. Fecal egg count reduction test (FECR) was calculated on day 22 PT. The study design used was a totally randomized block, with commercial feedlot and sex as block variables. For data analysis, a mixed model of the SAS statistical program was used. The FECR average on day 22 was $28.4 \%$ in the IVM group, and $94,2 \%$ in the RBZ group . From this date on, significant differences in EPG were kept until day 54. EPG counts were only equal near the end of the trial, on day $75(\mathrm{p}=0.16)$. In both commercial feedlots, especially in the IVM group, Cooperia spp. was the most prevalent parasite in the fecal cultures. Significant differences in weight $(\mathrm{P}<0.01)$ on post-treatment day 75 was found between the average weight in the RBZ and the IVM group ( $246 \mathrm{vs.} 238 \mathrm{~kg}$ respectively), what means a difference of $8.3 \%$ in gains. The importance for production in the antiparasite failure treatment in commercial feedlots was demonstrated, and the need of pos-treatment controls to evaluate the efficacy of the antiparasitic administered is emphasized.
\end{abstract}

INDEX TERMS: Feedlot, antihelmintic resistence, ivermectin, ricobendazole, calves.

RESUMO.- [Impacto de nematódeos gastrointestinais ivermectina-resistentes em bovinos em confinamento na Argentina.] 0 objetivo deste trabalho foi avaliar durante 75 dias o impacto sobre a produção da carga de parasita-

\footnotetext{
${ }^{1}$ Received on October 13, 2011.

Accepted for publication on January 30, 2012.

${ }^{2}$ Facultad de Ciencias Veterinarias, Universidad Nacional de La Plata, calle 60 y 118, CC 296, B1900AVW, La Plata, Argentina. *Corresponding author: fazzio@fcv.unlp.edu.ar

${ }^{3}$ Laboratorio Mesopotámico de Diagnóstico Veterinario, Ramírez 72, (3200) Concordia, Entre Ríos, Argentina.
}

-ivermectina (IVM) resistentes remanescentes em bezerros naturalmente infectados no confinamento. Os rebanhos são provenientes de áreas infestadas por carrapatos, onde o uso sistemático de IVM para o controle do carrapato aumenta a resistência de parasita gastrintestinais a esta droga. Este trabalho foi realizado em dois confinamentos comerciais na província de Buenos Aires. Na fazenda A, dois grupos de 35 animais cada receberam IVM 1\% e ricobendazole (RBZ) $10 \%$, respectivamente. 0 mesmo foi feito no confinamento B. No dia 0 , dois grupos de 35 animais foram feitos nas fazendas A e B. As amostras fecais foram tomadas nos dias $0,22,54$ e 75 pós-tratamento (PT) e o peso cor- 
poral foi registrado, de cada animal. Amostras fecais foram processadas para a contagem individual de ovos por grama (EPG). Amostras fecais foram agrupadas para a identificação do gênero parasitária. 0 teste de redução de ovos fecais (TROF) foi calculado no dia 22 PT. 0 desenho do estudo utilizado foi aquele dos blocos inteiramente randomizados, sendo confinamento comercial e sexo as variáveis de bloco. Para a análise dos dados, um modelo misto do programa estatístico SAS foi utilizado. A média TROF no dia 22 foi de $28,4 \%$ no grupo IVM e $94,2 \%$ no grupo RBZ. A partir desta data, diferenças significativas na EPG foram mantidas até o dia 54. Contas de OPG só foram iguais perto do fim do estudo, no dia $75(p=0,16)$. Em ambos os confinamentos comerciais, especialmente no grupo IVM, Cooperia spp. foram os parasitos mais prevalentes nas culturas fecais. Diferenças significativas no peso $(\mathrm{P}<0,01) 75$ dias pós-tratamento foram encontradas entre o peso médio nos grupos RBZ e IVM ( 246 vs $238 \mathrm{~kg}$, respectivamente), o que significa uma diferença de 8,3\% nos ganhos. A importância para a produção no tratamento da insuficiência antiparasitários em confinamento comercial foi demonstrada, bem como a necessidade de controles pós-tratamento para avaliar a eficácia dos antiparasitários administrados é enfatizada.

TERMOS DE INDEXAÇÃO: Confinamento, resistência antihelmíntica, ivermectin, ricobendazole, bezerros.

\section{INTRODUCTION}

Gastrointestinal parasitism is one of the main sanitary problems affecting yield in cattle production systems with consequences ranging from weight loss without clinical manifestations to death (Ames et al. 1969, Entrocasso 1994, Entrocasso et al. 2008). Ostertagia ostertagi, Cooperia spp., Trichostrongylus axei and Haemonchus contortus are the most important gastrointestinal parasites in calves, but their prevalence and importance vary in different regions of Argentina (Fiel \& Steffan 1994, Fiel et al. 1994, Caracostantogolo et al. 2005).

Macrocyclic lactones, especially ivermectin (IVM), are the most commonly used antiparisitic drugs in Argentina. Most of the times, IVM has been adopted as the only tool for anthelmintic control, without considering other epidemiologic variables (Sievers \& Alocilla 2007, Canul- Ku et al. 2011).

In Argentina, the first references to anthelmintic resistance to IVM in cattle were made by Fiel et al. $(2000,2001)$ and Anziani et al. (2001), and afterwards, cases of anthelmintic resistance to different chemical groups of drugs have been frequently described (Mejia et al. 2003, Anziani et al. 2004, Caracostantogolo et al. 2005).

In tick-infested areas of cattle breeding - as happens in the northeast of the country - the systematic use of IVM to control tick increases the gastrointestinal parasites resistant to this drug (Caracostantogolo et al. 2005, Canul-Ku et al. 2011).

Commercial feedlot is increasing in Argentina. In this kind of farms, efficiency, i.e. avoiding production loss, depends on the strict control of the sanitary variables. The administration of an endectocide when the animals enter to the feedlot is one of the most frequent routine measures used to eliminate endo and ectoparasites. However, its efficacy against the parasites in feedlot calves is usually not evaluated and possible failures could have effects on production.

The aim of this invesdtigation was to evaluate for 75 days the impact on production of the remaining burden of IVM-resistant parasites in feedlot calves.

\section{MATERIALS AND METHODS}

This study was carried out from April 2010 to January 2011 in two commercial feedlots. Feedlot A is located in Magdalena $\left(-35^{\circ} 05^{\prime} \mathrm{S}\right.$, $\left.-57^{\circ} 30^{\prime} \mathrm{W}\right)$ and feedlot B in Marcos Paz $\left(-34^{\circ} 08^{\prime} \mathrm{S}, 58^{\circ} 08 \mathrm{~W}\right)$, both in Buenos Aires province.

The livestock was bought, with unknown sanitary backgrounds, from livestock traders in northern Argentina. On their arrival at the feedlot, ten individual fresh fecal samples were taken for coproparasitologic analysis. Both groups were included in the experiment because the animals had been taken from tick-infested areas and the egg counts found in fecal samples were high: $510 \pm$ 234 in feedlot $\mathrm{A}$ and $460 \pm 470$ in feedlot B (average \pm standard deviation).

The animals had been carried $730 \mathrm{~km}$ and $810 \mathrm{~km}$ to reach feedlots A and B respectively. They were kept 72 hours for rest and rehydration. The diet in this period ( 72 hours) was based on rolls of hay. The sanitary routine before entering the feedlot was vaccinated with a polyvalent clostridial vaccine (Policlostrigen $®$ Biogénesis-Bagó) and $10 \mathrm{mg} / \mathrm{kg}$ injectable broad-spectrum antibiotics (Tilmicosina- Maxityl ${ }^{\circledR}$ Biogénesis-Bagó). Once the livestock entered in the pens, it was fed on diets formulated for this period and animal category. The ration contain: corn grains, sunflower expeller, chopped pasture hay, cottonseed culls, corn gluten, and micro ingredients (e.g. feed additives, minerals and vitamins). Fiber content in the diet was $23 \%$ for the first 7 days, decreasing gradually to 8 and $5 \%$ in the last stage of the fattening in feedlot A and B respectively.

\section{Animal selection and identification}

In feedlot $\mathrm{A}$, the herd had 70 Hereford female calves between 7 and 8 months old with an average live weight of $180 \mathrm{~kg}$. In feedlot B, there were 104 Hereford calves, male and female, between 5 and 6 months old with an average weight of $160 \mathrm{~kg}$ live. In each feedlot, seventy calves were selected at random. In both feedlots the animals chosen for the experiment were identified with an individual, correlative ear-tag number and remained in the same pen.

\section{Trial description}

When the trial started, on day 0 , two groups of 35 animals were made in feedlots A and B. Manual collection of fecal samples from the rectum and registration of individual weight were the subsequent procedures in each group. The first group received antiparasitic treatment with IVM 1\% (Ivomec® Merial) at a dose of $200 \mathrm{mcg} / \mathrm{kgpv}$ and the other was administered Ricobendazole (RBZ) $10 \%$ (Axilur PI® Intervet) at a dose of $7.5 \mathrm{mg} / \mathrm{kgpv}$, both subcutaneously administered. The next samplings were taken on days 22, 54 and 75 postreatment (PT), when fecal samples were collected from each animal and their body weight were registered.

\section{Sample processing}

Fecal samples were processed for individual count of egg per gram (EPG) by modified McMaster technique (Roberts \& O'Sullivan 1949). Besides, pooled fecal culture was carried out 
for the identification of parasite genus in each sampling (Niec 1968).

\section{Data calculations and statistical analysis}

The study design used was a totally randomized block, being feedlot and sex the block variables. For data analysis, a mixed model of the SAS statistical program was used (9.0). This model included animal and block as randomized factors; being treatment, time and interaction (treatment $x$ time) fixed factors. Due to the characteristics of the data collection, the variables weight and EPG were analyzed as measures repeated in time. To separate the time/treatment interaction averages, the option "slice" of this software was used. The initial weight and EPG of each animal were used as covariates for weight and EPG analysis respectively. As sex was not statistically significant in weight analysis, it was removed from the trial design. In the EPG analysis, neither sex nor feedlot was statistically significant, which determined their removal from the trial design.

The percentage of fecal egg count reduction (FECR) was calculated on day 22 PT, taking into account the low probability of reinfection in feedlot cattle. The formula used was: FECR $=100$ *[1- (T2/T1)], being T2 the EPG average on PT day 22 and T1 the EPG average on pretreatment day 0 (Mejia et al. 2003, Cristel \& Suarez 2006).

\section{RESULTS}

The results of the average EPG counts obtained throughout the trial are shown in Figure 1.

The FECR average on day 22 was $28.4 \%$ in the IVM group, and $94,2 \%$ in the RBZ group. From this date on, significant differences were kept until day 54 . Counts were only equal near the end of the trial, on day $75(\mathrm{p}=0,16)$.

The results of the fecal cultures in each sampling are shown in Table 1. In feedlot A, in the RBZ group larvae were not recovered on day 22 due to problems with its culture. Therefore the corresponding sampling on day 22 (RBZ group) shows the results obtained only in the feedlot $\mathrm{B}$.

In the IVM group, Cooperia spp. were the most prevalent parasite in fecal cultures, in the RBZ group, Cooperia spp. and Haemonchus spp. were the most prevalent parasite genus, depending on the sampling day (Table 1 ).

The evolution in animal weight is shown in Table 2. At

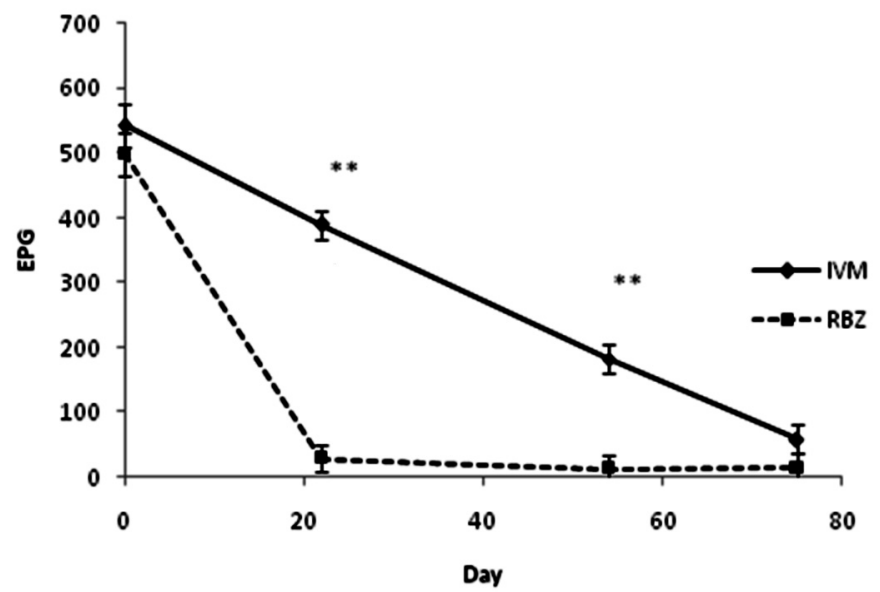

Fig.1. Eggs per gram of faeces (EPG) from zero to 75 days in feedlot calves, after receiving Ivermectin (IVM) and Ricobendazole (RBZ). ${ }^{* *}$ P value $<0.01$, of slice option.
Table 1. Feedlot A: Percentage of parasite larvae in Ivermectin (IVM) and Ricobendazole (RBZ) groups on different sampling days

\begin{tabular}{clcccc}
\hline Group & \multicolumn{1}{c}{ Parasite } & \multicolumn{4}{c}{ Day } \\
\cline { 3 - 6 } & & 0 & 22 & 54 & 75 \\
\hline \multirow{2}{*}{ IVM } & Cooperia spp. & $82 \%$ & $96 \%$ & $90 \%$ & $82 \%$ \\
& Haemonchus spp. & $10 \%$ & $4 \%$ & $10 \%$ & $18 \%$ \\
& Ostertagia spp. & $2 \%$ & $0 \%$ & $0 \%$ & $0 \%$ \\
& Trichostrongylus spp. & $2 \%$ & $0 \%$ & $0 \%$ & $0 \%$ \\
& Oesophagostomun spp. & $4 \%$ & $0 \%$ & $0 \%$ & $0 \%$ \\
RBZ & Cooperia spp. & $82 \%$ & $16 \%$ & $58 \%$ & $64 \%$ \\
& Haemonchus spp. & $10 \%$ & $84 \%$ & $32 \%$ & $27 \%$ \\
& Ostertagia spp. & $2 \%$ & $0 \%$ & $4 \%$ & $5 \%$ \\
& Trichostrongylus spp. & $2 \%$ & $0 \%$ & $6 \%$ & $4 \%$ \\
& Oesophagostomun spp. & $4 \%$ & $0 \%$ & $0 \%$ & $0 \%$
\end{tabular}

Table 2. Weight ( \pm standart error) in calves in feedlot for 75 days, treated with Ivermectin (IVM) and Ricobendazole (RBZ)

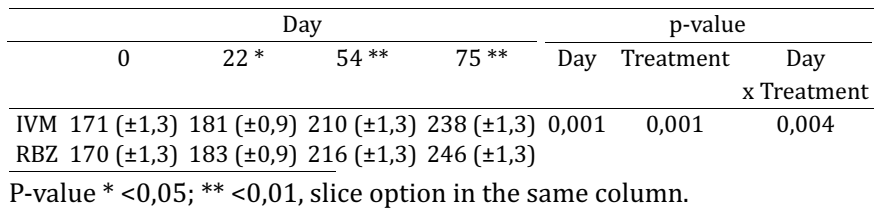

the end of the trial, on post-treatment day 75, a difference $(\mathrm{P}<0.01)$ of $8 \mathrm{kgs}$. was found between the average weight in the RBZ and IVM groups (246 vs. $238 \mathrm{~kg}$ respectively), which means a difference of $8.3 \%$ in gains.

\section{DISCUSSION}

IVM is a broad-spectrum drug against gastrointestinal and pulmonary nematodes as well as against ectoparasites in domestic animals (Lanusse 1994). These characteristics were deciding factors for the choice of this drug to prevent parasite diseases when the calves entered at the feedlot. However, a decade ago, several reports marked the presence of IVM-resistant nematodes worldwide (Mc Kenna 1991, Jackson et al. 1995, Staford \& Cooles 1999, Paiva et al. 2001, Gasbarre et al. 2009). In a survey based on the fecal egg reduction test carried out in 2005 in 69 commercial cow-calf operation in 8 Argentinean provinces, $55 \%$ of the cattle feedlots showed different IVM resistance levels and some herds were resistant to more than one antiparasitic chemical group (Caracostantogolo et al. 2005).

In this trial, Cooperia spp. were the parasite genus prevailing in IVM post-treatment cultures, showing consistency with previous data presenting this parasite as the most frequently IVM-resistant one in cattle in Argentina (Fiel et al. 2001, Caracostantogolo et al. 2005). Although Cooperia spp. are not considered one of the most pathogenic genus in cattle. However trials carried out with this genus show its pathogenic power (Herlich 1965, Keith 1967). A recent work, with artificially C. punctata infected feedlot calves, shows an economically important effect on appetite, nutrient uptake and body weight gain, compared with control calves (Stromberg et al. 2011). Its weak pathogenicity hides the resistance effect longer, since lower subclinical manifestations, such as lower daily weight gain (DWG), can be unnoticed. 
In the northeast of Argentina, Cooperia spp. and Haemonchus spp. are the most prevalent parasites in faecal cultures of animals younger than 1 year old (Fiel et al. 1994), data which coincide with the genus found in the present paper. Most of this region is included in the area of distribution of the common cattle tick (Riphicephalus microplus, formerly Boophilus microplus). The risk of selecting gastrointestinal resistant parasite to this drug is increased by the administration of IVM to control ectoparasites, which are carried by the livestock to the fattening areas (Fiel et al. 2005, Canul- Ku et al. 2011). In this study, the use of RBZ as an alternative to IVM at the beginning of the fattening cycle proved to be more efficient in calves coming from the northeast. However, resistance to benzimidazoles in cattle has also been recorded (Anziani et al. 2004, Caracostantologo et al. 2005, Fiel et al. 2005, Gasbarre et al. 2009), showing that although the use of this drug reduces the probability of failures in the treatment it does not eliminate possible flaws.

By evaluating the FECR it became evident that the RBZ group showed a higher percentage of efficacy $(94,2 \%)$. However, it did not reach the $95 \%$ considered as the efficacy limit to control the disease and the production loss (Coles et al. 2006).

In this study differences of $8 \mathrm{~kg}$ in average weight per animal were found between the RBZ and the IVM groups 75 days after the fattening cycle started. Taking into account the capacity of the feedlots in this study varied between 150 and 250 animals, losses between 1,200 and 2,000 meat $\mathrm{kg}$ per pen and per fattening cycle could be expected. These losses, caused by the effect of Cooperia spp resistant to IVM, could even be bigger if animals hosting more pathogenic genera of antiparasitics-resistant parasites had entered the feedlot. There are no data showing if the difference in kilogram between calves free of parasites and another with a higher amount of them is maintained, decreases or increases nearing the end of the fattening cycle. Compensatory DWG were described in feedlots in the USA (Ames et al. 1969) where the fattening cycles are longer than the ones in Argentina. Nevertheless, more trials should be carried out to evaluate this possibility. In this trial, weight difference remained throughout the study without compensatory DWG in the IVM group, even when the EPG count was significantly reduced.

The importance for production of breakdowns in the antiparasite treatment in commercial feedlots was demonstrated, and the need of pos-treatment controls to evaluate the efficacy of the antiparasitic administered is emphasized. More research is necessary to establish a threshold for EPG count tolerance without subclinical losses in production. In this sense, narrow-spectrum drugs with lower degree of resistance for specific types of parasites could be administered on arrival, but they should be analyzed for each group of animals in particular.

\section{CONCLUSION}

PT remaining parasites have an impact on production, even Cooperia spp. which did not affect the animals clinically, but altered production performance during the first 75 days in the commercial feedlots. The antiparasitic treatments administered should be analyzed regularly to guarantee an efficient de-worming. Regarding this aspect, more research is required to quantify the effect of other types of parasites and of lower EPG remaining burden.

Acknowledgments.- Appreciation is expressed to Maria Eugenia Araujo and Alejandro E. Relling for the assistance during this study. EJG is Research Member of CONICET (Consejo Nacional de Investigaciones Científicas y Técnicas).

\section{REFERENCES}

Ames E.R., Rubin R. \& Matsushima J.K. 1969. Effects of gastrointestinal nematode parasites on performance in feedlot cattle. J. Anim. Sci. 28:698704.

Anziani O.S., Guglielmone A.A., Zimmermann G., Vazquez R. \& Suarez V.R. 2001. Avermectin resistance to Cooperia pectinata in cattle in Argentina. Vet. Rec. 149:58-59.

Anziani O.S., Suarez V., Guglielmone A.A., Wanker O., Grande H. \& Coles G. 2004. Resistance to benzimidazole and avermectin anthelmintics in cattle nematodes in Argentina. Vet. Parasitol. 122:303-306.

Canul-Ku H.L., Rodríguez-Vivas R.I., Torres-Acosta J.F., Aguilar-Caballero A.J., Pérez-Cogollo L.C. \& Ojeda-Chi M.M. 2011. Prevalence of cattle herds with ivermectin resistant nematodes in the hot sub-humid tropics of Mexico. Vet. Parasitol. (2011), doi:10.1016/ j.vetpar. July 29, 2011.

Caracostantogolo J., Castaño R., Cutullé Ch., Cetrá B., Lamberti R., Olaechea F., Ruiz M., Schapiro J., Martínez M., Balbiani G. \& Castro M. 2005. Evaluación de la resistencia a los antihelmínticos en rumiantes en Argentina, p.7-34. In: Eddi C. \& Vargas Terán M. (Eds), Resistencia a los Antiparasitarios Internos en Argentina. FAO Producción y Sanidad Animal, Roma, Italia.

Coles G.C., Jackson F., Pomroy W.E., Prichard R.K., Samson-Himmelstjerna G. von, Silvestre A., Taylor M.A. \& Vercruysse J. 2006. The detection of anthelmintic resistance in nematodes of veterinary importance. Vet. Parasitol. 136(3/4):167-185.

Cristel S.L. \& Suarez V.H. 2006. Resistencia antihelmíntica: evaluación de la prueba de reducción del conteo de huevos. Revta Invest. Agropec. RIA 35 (3):29-43.

Entrocasso C. 1994. Fisiopatología del parasitismo gastroentérico, p. 3-17. In: Nari A. \& Fiel C.A. (Eds), Enfermedades Parasitarias de Importancia Económica en Bovinos: bases epidemiológicas para su prevención y control. Hemisferio Sur, Montevideo, Uruguay.

Entrocasso C., Alvarez L., Manazza J., Lifschitz A., Borda B., Virkel G., Mottier L. \& Lanusse C. 2008. Clinical efficacy assessment of the albendazole-ivermectin combination in lambs parasitized with resistant nematodes. Vet. Parasitol. 155(3/4):249-256.

Fiel C.A. \& Steffan P.E. 1994. Epidemiología de los nematodes gastrointestinales en la Pampa Húmeda, p.67-94. In: Nari A. \& Fiel C. (Eds), Enfermedades Parasitarias de Importancia Económica en Bovinos. Editorial Hemisferio Sur, Montevideo, Uruguay.

Fiel C., Daffner A. \& Alvarez J. 1994. Epidemiología de los nematodes gastrointestinales en la región subtropical, p:115-129. In: Nari A. \& Fiel C.A. (Eds), Enfermedades Parasitarias de Importancia Económica en Bovinos: bases epidemiológicas para su prevención y control. Editorial Hemisferio Sur, Montevideo, Uruguay

Fiel C., Saumell C., Steffan P., Rodriguez E. \& Salabarry G. 2000. Resistencia de los nematodes trichostrongylideos Cooperia y Trichostrongylus a tratamientos con avermectinas en bovinos de la pampa húmeda Argentina. Revta Med. Vet. 81:310-315.

Fiel C.A., Saumell C., Steffan P. \& Rodriguez E. 2001. Resistance of Cooperia to ivermectin treatments in grazing cattle of the humid pampa, Argentina. Vet. Parasitol. 97:213-21.

Fiel C.A., Saumell C.A., Fusé L.A., Seguí R., Freije E., Steffan P.E. \& Iglesias L.E. 2005. Resistencia Antihelmíntica en Bovinos: dos escenarios diferentes como resultado de (1.) El sistema de manejo y (2.) La excesiva 
frecuencia de tratamientos antiparasitarios. FAO Producción y Sanidad Animal. Resistencia a los Antiparasitarios Internos en Argentina, p.5360. FAO, Roma.

Gasbarre LC., Smith LL., Lichtenfels J.R. \& Pilitt P.A. 2009. The identification of cattle nematode parasites resistant to multiple classes of anthelmintics in a commercial cattle population in the U.S. Vet. Parasitol.166: 281-285.

Herlich H. 1965. The effects of the intestinal worms Cooperia pectinata and Cooperia oncophora, on experimentally infected calves. Am. J. Vet. Res. 26(114):1032-1036.

Jackson R.A., Townsend K.G., Pyke C. \& Lance D.M. 1995. Isolation of oxfendazole resistant Cooperia oncophora in cattle. N. Z. Vet. J. 35:187-189.

Keith R.K. 1967. The pathogenicity of experimental infections of Cooperia pectinata Ransom, 1907 in calves. Aust. J. Agric. Res. 18:861-864.

Lanusse C.E. 1994. Bases farmacologicas de la terapeutica antihelmintica, p.33-65. In: Nari A. \& Fiel C.A. (Eds), Enfermedades Parasitarias de Importancia Económica en Bovinos: bases epidemiológicas para su prevención y control, Hemisferio Sur, Montevideo, Uruguay.

McKenna P.B. 1991. Resistance to benzimidazole anthelmintic in cattle in New Zealand. N. Z. Vet. J. 39:154-155.

Mejia M. E., Fernández Igartúa B.M., Schmidt E.E. \& Cabaret J. 2003. Mul- tispecies and multiple anthelmintic resistance on cattle nematodes in a farm in Argentina: the beginning of high resistance. Vet. Res. 34:461467.

Niec R. 1968. Cultivo e identificación de larvas infectantes de nematodes gastrointestinales del bovino y ovino, p.1-37. Manual Técnico no 3, Instituto Nacional de Tecnología Agropecuaria (INTA), Argentina.

Paiva F., Sato M.O., Acuña A.H., Jensen J.R. \& Bressan M.C.R.V. 2001. Resistencia a ivermectina constatadas em Haemonchus placei e Cooperia punctata em bovinos. Hora Vet., Porto Alegre, 20:29-32.

Roberts F.H.S. \& O'sullivan P.J. 1949. Methods for egg counts and larval cultures for strongyles infesting the gastrointestinal tract of cattle. Aust. J. Agric. Res. 24:947-953.

Sievers G. \& Alocilla A. 2007. Determinación de resistencia antihelmíntica frente a ivermectina de nematodos del bovino en dos predios del sur de Chile. Arch. Med. Vet. 39:67-69.

Stafford K. \& Coles G.C. 1999. Nematode control practices and anthelmintic resistance in dairy calves in the south west of England. Vet. Rec. 144:659-661.

Stromberg B.E., Gasbarre L.C., Waite A., Bechtol D.T., Brown M.S., Robinson N.A., Olson E.J. \& Newcomb H. 2011. Cooperia punctata: Effect on cattle productivity? Vet. Parasitol., doi: 10.1016/j.vetpar. July 30, 2011. 